\title{
Irreversible effects of dichloromethane on the brain after long term exposure: a quantitative study of DNA and the glial cell marker proteins S-100 and GFA
}

\author{
L E ROSENGREN, ${ }^{1}$ P KJELLSTRAND, ${ }^{2}$ A AURELL, ${ }^{1}$ AND K G HAGLID ${ }^{1}$ \\ From the Institute of Neurobiology, ${ }^{1}$ University of Göteborg, Göteborg and Institute of Zoophysiology, ${ }^{2}$ \\ University of Lund, Lund, Sweden
}

ABSTRACT Two astroglial proteins S-100 and GFA, as well as DNA, were quantitatively determined in different regions of the gerbil brain after continuous long term exposure to moderate concentrations of dichloromethane. The intention of the experiment was to expose three groups of animals at three different solvent concentrations $(210,350$, or $700 \mathrm{ppm})$ for three months. Because of the high mortality rate, however, the $700 \mathrm{ppm}$ experiment was terminated after seven weeks. In the 350 ppm experiment half the exposed animals died and the exposure period was terminated after ten weeks. After the exposure period, the surviving gerbils in the $350 \mathrm{ppm}$ exposure group and those from the $210 \mathrm{ppm}$ group were allowed a postexposure solvent free period of four months. After exposure to $350 \mathrm{ppm}$, increased concentrations of the two astroglial proteins were found in the frontal and sensory motor cerebral cortex, compatible with astrogliosis in these regions. Exposure to $350 \mathrm{ppm}$ and $210 \mathrm{ppm}$ decreased the concentrations of DNA in the hippocampus. Moreover, after exposure at $350 \mathrm{ppm}$, DNA concentrations were also decreased in the cerebellar hemispheres. These results indicate a decreased cell density in these brain regions, probably due to cell loss. The neurotoxic effects were not found to correlate with the endogenous formation of carbon monoxide.

The adverse effects associated with exposure to dichloromethane (methylene chloride $\mathrm{CH}_{2} \mathrm{Cl}_{2}$ ) are primarily neurological and cardiovascular. ${ }^{12}$ Effects on the central nervous system are related to the anaesthetic properties of the solvent, and exposure of man to dichloromethane at $500-1000 \mathrm{ppm}$ has been shown to cause early signs of central nervous system depression. ${ }^{13}$ Dizziness and lethargy, nausea, unconsciousness, and even death may result from accidental exposure to high concentrations. ${ }^{4}$

In the occupational setting diffuse toxic brain damage resulting in visual and auditory illusions has been reported after chronic exposure to dichloromethane. ${ }^{56}$ Bilateral temporal lobe degeneration has been described in one individual after long term occupational exposure to high concentrations of dichloromethane. The symptoms included loss of memory, mental deterioration, headache, and dysarthria; and an air encephalogram showed minor increases in subarachnoid air shadows in both frontal areas. $^{7}$

Although several studies on animals have been performed after acute or short term exposure to dichlo-

Accepted 9 September 1985 romethane, to our knowledge none has been concerned with the biochemical or morphological effects on the central nervous system after chronic exposure.

The purpose of this study is to describe the effects of chronic dichloromethane exposure on the astroglial cell population in different brain regions by showing the altered concentrations of two astroglial cell marker proteins, S-100 and GFA. ${ }^{89}$ Traumatic damage to the central nervous system tissue is frequently a cause of hypertrophy or proliferation of astroglial cells, or both, as has been shown by immunohistochemical methods using specific antibodies to astroglial proteins. ${ }^{10-12}$ Furthermore, astrogliosis as a consequence of trauma to the brain is well known in human neuropathology. Previous studies in our laboratory have shown that chronic exposure to trichloroethylene or ethanol can induce increased concentrations of S-100 in different regions of the gerbil brain compatible with the presence of astrogliosis. ${ }^{1314}$

The intention of the experiment was to expose gerbils by continuous inhalation to dichloromethane at 210,350 , or $700 \mathrm{ppm}$ for three months, followed by a postexposure solvent free period of four months. After this last period, concentrations of S-100, GFA, 
DNA, and protein in various regions of the brain were quantitatively measured.

A major toxicological hazard of dichloromethane in the brain during acute exposure is considered to be the formation of carbon monoxide during biotransformation. ${ }^{115}$ In a complementary study the carboxyhaemoglobin per cent saturation was determined in the blood of gerbils continuously exposed for three weeks at 210 and $350 \mathrm{ppm}$.

\section{Materials and methods}

\section{MATERIALS}

Barbital, sodium barbital, sodium azide, sodium chloride, Perhydrol $\left(30 \% \mathrm{H}_{2} \mathrm{O}_{2}\right)$, tris, glycine, EDTA, and 2-mercaptoethanol were of analytical grade (Merck, Germany). Agarose HSA (Litex, Denmark), 96 well flat bottom microtest plates (NUNC, Denmark), peroxidase conjugated swine antirabbit IgG (Dako, Denmark), salmon DNA, bovine albumin, o-phenylenediamine, and diaminobenzidine (Sigma Chemical Co, USA) and nitrocellulose membranes, acrylamide, bisacrylamide, Commassie brilliant blue, and SDS (Bio-Rad, USA) were used. Commercial dichloromethane, cleaning grade, containing $0.3-0.5 \%$ stabilisers (butylene oxide and antioxidants) was obtained from Billerud AB (Sweden).

\section{ANIMALS}

Seventy six male and 60 female Mongolian gerbils (Meriones ungiculatus) were used. The initial mean weight of the male gerbils was $72.8 \mathrm{~g} \pm 1.9$ (SE) and of the females $57.8 \pm 1.0$ (SE). Male and female animals were housed separately in transparent plastic cages $(45 \times 24 \times 15 \mathrm{~cm}$, four or five to a case). Experimental and control animals were sex matched littermates. Commercial laboratory rat food (Astra/Ewos, Sweden) and water were freely available. Sawdust was used as bedding. The environmental temperature was kept to $22^{\circ} \mathrm{C} \pm 2{ }^{\circ} \mathrm{C}$. Light supplementing daylight was automatically controlled for 12 hours daylight, with half an hours twilight at dawn and evening.

\section{EXPOSURE}

During the experimental runs, exposure was continuous. Dichloromethane was injected into a temperature controlled glass vapouriser $\left(60^{\circ} \mathrm{C}\right)$, mixed with a small volume of air $(20 \mathrm{l} / \mathrm{h})$, and subsequently diluted with clean air $(1000 \mathrm{l} / \mathrm{h})$ to produce the desired concentration. The concentration in the inhalation chambers was monitored with a Miran 1A spectrophotometer fitted with a multipath gas cell. All air was filtered to remove oil and particles larger than 0.3 $\mu \mathrm{m}$. The long term stability of the system permitted a concentration of solvent to be held within $10 \%$ of the target concentration. Interruptions occurred for only one to two hours a week for changing of water, bedding material, and food. Control animals were exposed to clean air $(1000 \mathrm{l} / \mathrm{h})$.

Three experiments were performed: gerbils were exposed to 210,350 , or $700 \mathrm{ppm}$. At each solvent concentration 10 male and 10 female gerbils were exposed; 60 sex matched littermates served as controls. The intention was to expose the experimental groups for three months. Because, however, of the high mortality rate in the $700 \mathrm{ppm}$ exposure group, this exposure was terminated after seven weeks. In the $350 \mathrm{ppm}$ group half the animals died during the ninth and tenth week and as a result the exposure of this group was terminated after 10 weeks. The $210 \mathrm{ppm}$ group was exposed as planned for three months. The littermate controls were housed in chambers identical to those of the experimental animals throughout the experimental period. After the exposure period, all surviving animals were removed from the inhalation chambers and kept free of exposure for four months.

PREPARATION OF TISSUE

After the solvent free period, four male and four $\overrightarrow{0}$ female gerbils from each of the two remaining experiments and 16 littermate controls, were killed. The brains were removed and dissected on ice. The cerebral cortices were divided lengthwise into three equal parts, frontal, middle, and dorsal. The cerebellar hemispheres were divided at the position of the sulci intercrurales into anterior and posterior parts. The anterior (lobuli I-V) and posterior (lobuli VI-X) cerebellar vermis and the brainstem (under the 4th ventricle) and the hippocampus were also dissected. Tissue samples were weighed, then quickly frozen on solid ice and stored in tight fitting boxes at $-80^{\circ} \mathrm{C}$ until analysed. Tissues were homogenised at $1: 5$ or 1:20

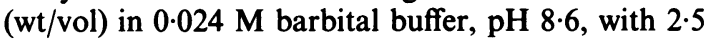
mM EDTA and 1.0 mM 2-mercaptoethanol; they were then centrifuged at $50000 \mathrm{~g}$ for 60 minutes.

ANALYTICAL PROCEDURE

Protein concentrations in the homogenates were $D$ determined according to Lowry et al. ${ }^{16}$ Bovine serum albumin was used as a reference standard.

The S-100 concentrations were measured in the supernatants by rocket immunoelectrophoresis. ${ }^{17}$ Bovine S-100 was used as a reference standard.

Analyses of the DNA concentrations in the $\bar{O}$ homogenates were carried out according to Kissane 0 and Robins. ${ }^{18}$ Salmon DNA was used as a reference standard.

GFA concentrations were determined in the super- $T$ natants by a solid phase ELISA-technique. ${ }^{19} \mathrm{~A}$ first layer, normal gerbil brain supernatant in incubation buffer $(0.024 \mathrm{M}$ barbital buffer, $\mathrm{pH} 8 \cdot 6$, containing

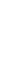


$1.0 \mathrm{mM}$ 2-mercaptoethanol, $2.5 \mathrm{mM}$ EDTA, 1.0 $\mathrm{U} / \mathrm{ml}$ aprotinin, and $0.1 \%$ sodium azide) was absorbed on to flat bottom polystyrene microtest plates by incubating overnight at $+4^{\circ} \mathrm{C}$. A total of $5 \cdot 4$ $\mu \mathrm{g}$ brain protein was applied per well. The plates were washed in $0.15 \mathrm{M} \mathrm{NaCl}$, containing $0.05 \%(\mathrm{v} / \mathrm{v})$ TWEEN-20 and incubated with $0.5 \%$ albumin (w/v) in incubation buffer for four hours at room temperature, and they were subsequently washed again. After $50 \mu$ incubation buffer had been added to each well, followed by $5 \mu$ l samples or reference gerbil supernatant, $50 \mu \mathrm{l}$ anti-GFA diluted 1:4000 was subsequently added to each well and the plates were incubated for five hours at room temperature. After washing, peroxidase conjugated swine antirabbit IgG, diluted 1:200, was added to each well and allowed to incubate overnight at $+4^{\circ} \mathrm{C}$. The plates were then washed and enzyme substrate was added: ophenylenediamine, $0.5 \mathrm{mg} / \mathrm{ml}$ in $50 \mathrm{mM}$ citrate buffer, pH 5.0 , containing $0.01 \% \mathrm{H}_{2} \mathrm{O}_{2}$. The reaction was stopped with $1.0 \mathrm{M} \mathrm{H}_{2} \mathrm{SO}_{4}$ and the absorbance was measured at $490 \mathrm{~nm}$ in an automatic ELISA-reader (Flow, USA). The arbitrary unit (AU) used refers to the amount of GFA in $1 \mu$ l of the reference gerbil supernatant. Experiments in our laboratory indicate that the extraction procedure used allows solubilisation of about a quarter of the total GFA in gerbil brain tissue (unpublished observation), which is in good agreement with the findings of Gheuens et al. ${ }^{20}$

\section{ANTIBODIES}

The S-100 antibodies were prepared according to Haglid et $a .^{21}$ The GFA antibodies were prepared according to Dahl and Bignami. ${ }^{22}$ The specificity of the antibodies to GFA was demonstrated by immunoblotting. Samples of the reference gerbil supernatant containing $54 \mu \mathrm{g}, 162 \mu \mathrm{g}$, and $270 \mu \mathrm{g}$ protein were run in SDS gel electrophoresis, performed in a $5-10 \%$ linear gradient polyacrylamide slab gel. ${ }^{23}$ The proteins were transferred to a nitrocellulose membrane according to Towbin et al, ${ }^{24}$ except that $0.1 \%$ SDS was added to the transferbuffer. The electrophoretic blots were detected using anti-GFA (diluted 1:10000 in tris buffered saline) as the first antibody and peroxidase conjugated swine antirabbit IgG (diluted 1:200) as the second antibody. Diaminobenzidine $(0.5 \mathrm{mg} / \mathrm{ml}$ in tris buffered saline) and $\mathrm{H}_{2} \mathrm{O}_{2}(0.03 \%)$ was used as enzyme substrate for the colour reaction.

\section{DETERMINATIONS OF}

\section{CARBOXYHAEMOGLOBIN PER CENT}

SATURATION

Eight littermate male pairs of gerbils were continuously exposed to dichloromethane for three weeks; eight were exposed at $210 \mathrm{ppm}$ and the lit- termates at $350 \mathrm{ppm}$. At the end of the exposure the animals were removed from the inhalation chambers and immediately bled. Carboxyhaemoglobin per cent saturation was determined according to Collison et $a l^{25}$ as modified by Lundh et al. ${ }^{26}$

\section{STATISTICAL EVALUATION}

Fisher's non-parametric permutation test for paired observations was used. ${ }^{27}$

\section{Results}

\section{MORTALITY, BODY AND BRAIN WEIGHTS}

The exposure at $700 \mathrm{ppm}$ was terminated after seven weeks because of the high mortality rate among the exposed animals (fig 1). Between day 28 and day 52 of the experiment, 10 male and nine female gerbils died. The mean survival time in days of these animals was $38.6 \pm 2.0$ (SE) for male and $36.1 \pm 3.3$ (SE) for female animals. No control animals died during the experimental period. During the exposure period the exposed animals lost weight compared with the controls (fig 1).

The exposure at $350 \mathrm{ppm}$ was terminated after 10 weeks, also because of the high mortality rate among the exposed animals (fig 1). Between days 63 and 71 of the experiment six male and three female gerbils died.
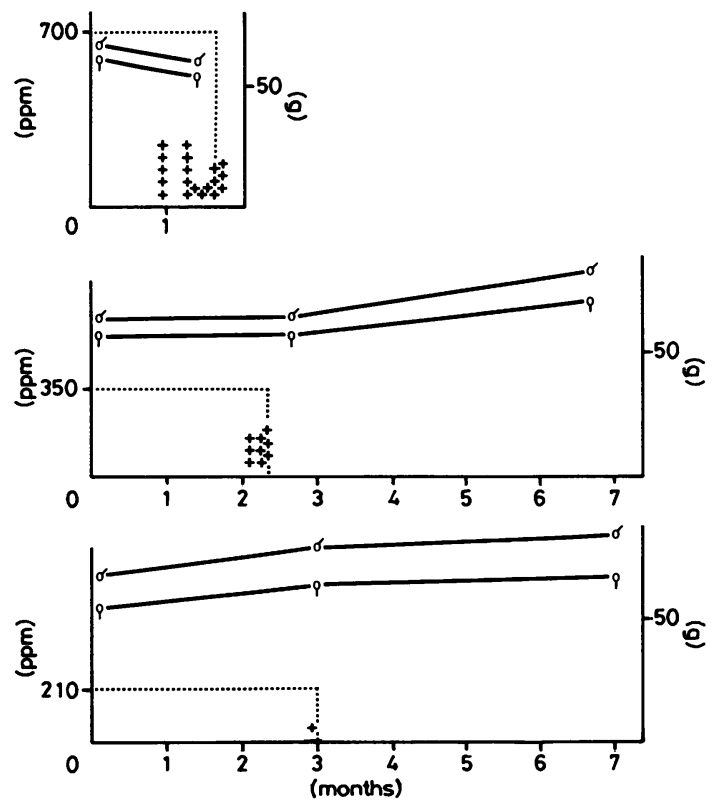

Fig 1 Weight development among dichloromethane exposed gerbils at three different exposure levels. $\delta$ : male gerbils. $Q$ : female gerbils. - : weight. --- : ppm. + : indicates death of one gerbil. 
The mean survival time in days of these animals was $67.5 \pm 1.5$ (SE) for male and $66.0 \pm 1.5$ (SE) for female animals. No control animals died during the experiment. A depressed weight gain was observed among the exposed animals during exposure (fig 1). At the end of the exposure period (day 70) the exposed animals weighed significantly less compared with the littermate controls $(p \leqslant 0.05)$. During the postexposure period, however, the exposed animals gained weight and at the end of the experiment exposed and control animals had similar weights (fig 1).

The exposure at $210 \mathrm{ppm}$ was continued for three months as planned. One exposed female gerbil died at day 88. No control animals died. During the exposure period, the exposed animals gained weight normally and no significant difference in weight between exposed and control animals was observed at the end of the exposure period or at the end of the experiment.

Brain weights did not differ between control and exposed animals, neither after exposure at $210 \mathrm{ppm}$ nor after exposure at $350 \mathrm{ppm}$. The weights of the dissected brain areas were significantly increased in the cerebral sensory motor cortex after exposure at $350 \mathrm{ppm}(\mathrm{p} \leqslant 0.05)$. The weights of the other brain areas at this exposure level and $210 \mathrm{ppm}$ were not significantly changed $(p>0.05)$.

\section{S-100 PROTEIN}

The S-100 concentrations per wet weight in the different brain areas studied were not significantly altered after exposure to dichloromethane at 210 $\mathrm{ppm}$. Increased concentrations were found in the cerebral frontal cortex and in the sensory motor cortex after exposure at $350 \mathrm{ppm}$, however (fig 2).

\section{GFA PROTEIN}

The GFA concentrations per wet weight were significantly raised in both the cerebral frontal cortex and the cerebral sensory motor cortex in the animals exposed to dichloromethane at $350 \mathrm{ppm}$. The GFA concentrations per wet weight, however, were not significantly altered in these areas after exposure at 210 ppm (fig 3).

\section{DEOXYRIBONUCLEIC ACID}

DNA concentrations per wet weight were significantly decreased in the hippocampus after exposure at 210 and $350 \mathrm{ppm}$ dichloromethane. The DNA concentrations were also found to be decreased in the cerebellar hemispheres after exposure to $\mathbf{3 5 0}$ ppm (fig 4).

\section{PROTEINS}

Protein concentrations per wet weight in the different
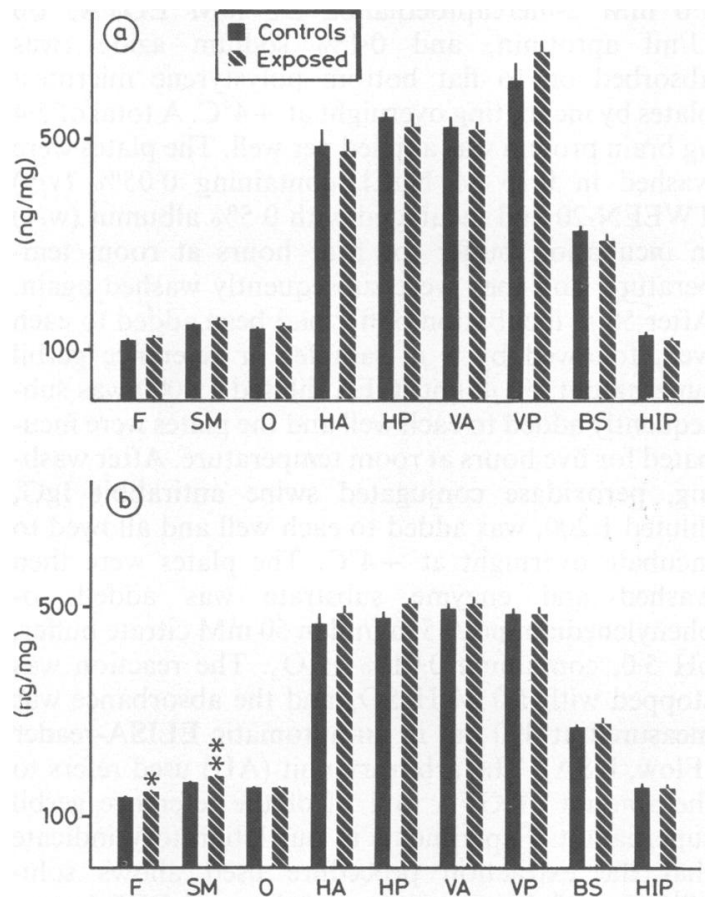

Fig 2 S-100 protein concentrations per wet weight (ng/mg) in gerbil brain areas after exposure to dichloromethane at (a) $210 \mathrm{ppm}$ for three months and (b) $350 \mathrm{ppm}$ for two months, followed by a postexposure solvent free period of four months. F: frontal cerebral cortex; SM: sensory motor cerebral cortex; O: occipital cerebral cortex; $\mathrm{HA}$ : anterior cerebellar hemispheres; HP: posterior cerebellar hemispheres; VA: anterior cerebellar vermis; VP: posterior cerebellar vermis; BS: brain stem; HIP: hippocampus. Bars represent mean values of eight animals and SEM. ${ }^{*} p<0.05$; ${ }^{* *} p<0.01$.

regions studied were not significantly changed after exposure to dichloromethane when compared with controls.

To exclude the possibility that the changes observed regarding S-100, GFA, and DNA concentrations per wet weight are due to a changed dry/wet weight ratio in the tissue samples, S-100, GFA, and DNA were also calculated as concentrations per protein. These results (fig 5) are in agreement with the results as calculated per wet weight (figs 2-4).

\section{IMMUNOBLOTTING OF REFERENCE}

SUPERNATANT

Only one band was found to be GFA immunoreactive when the reference gerbil brain supernatant was subjected to SDS-electrophoresis and transferred to a nitrocellulose membrane (fig 6). 


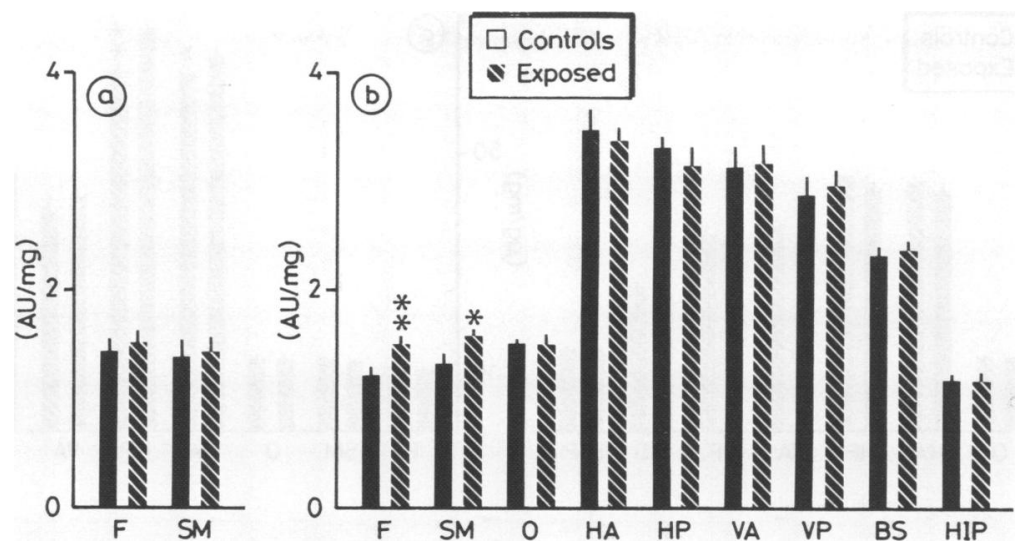

Fig $3 G F A$ protein concentrations per wet weight ( $A U / m g$ ) in gerbil brain areas after exposure to dichloromethane at (a) $210 \mathrm{ppm}$ for three months and (b) $350 \mathrm{ppm}$ for two months, followed by a postexposure solvent free period of four months. F: frontal cerebral cortex; SM: sensory motor cerebral cortex; $O$ : occipital cerebral cortex; HA: anterior cerebellar hemispheres; HP: posterior cerebellar hemispheres; VA: anterior cerebellar vermis; VP: posterior cerebellar vermis; BS: brain stem; HIP: hippocampus. Bars represent mean values of eight animals and SEM. ${ }^{*} p<0.05 ;{ }^{* *} p<0.01$.

\section{CARBOXYHAEMOGLOBIN PER CENT SATURATION}

No significant difference in carboxyhaemoglobin saturation was observed among the animals continuously exposed to dichloromethane for three weeks. The mean value for the $210 \mathrm{ppm}$ group was $11 \cdot 5 \pm 0 \cdot 4(\mathrm{SE})$ and for the $350 \mathrm{ppm}$ group $10 \cdot 3 \pm 0 \cdot 7$ (SE).

\section{Discussion}

In this study the levels of exposure were three, five, and ten times the current Swedish threshold limit value (TWA: $70 \mathrm{ppm}$ ). The intention of the experiments was to expose the animals by continuous inhalation for three months, as previous studies have shown this period to be sufficient to induce lasting alterations in different brain regions after exposure to trichloroethylene and ethanol. ${ }^{1314}$ Because of the $95 \%$ mortality rate in the $700 \mathrm{ppm}$ group during the second month of exposure, however, this experiment was terminated after seven weeks of exposure, and as the mortality rate in the $350 \mathrm{ppm}$ group was $45 \%$ at the beginning of the third month, the exposure was terminated after 10 weeks. Only the $210 \mathrm{ppm}$ group was exposed for three months as planned. As in our previous studies of the chronic neurotoxicity of trichloroethylene and ethanol, ${ }^{1314}$ the surviving animals were then subjected to a solvent free postexposure period of four months to allow sufficient time for regeneration and restoration of neuronal function. ${ }^{28}$ The high mortality among the gerbils had not been expected and no necropsy of these animals
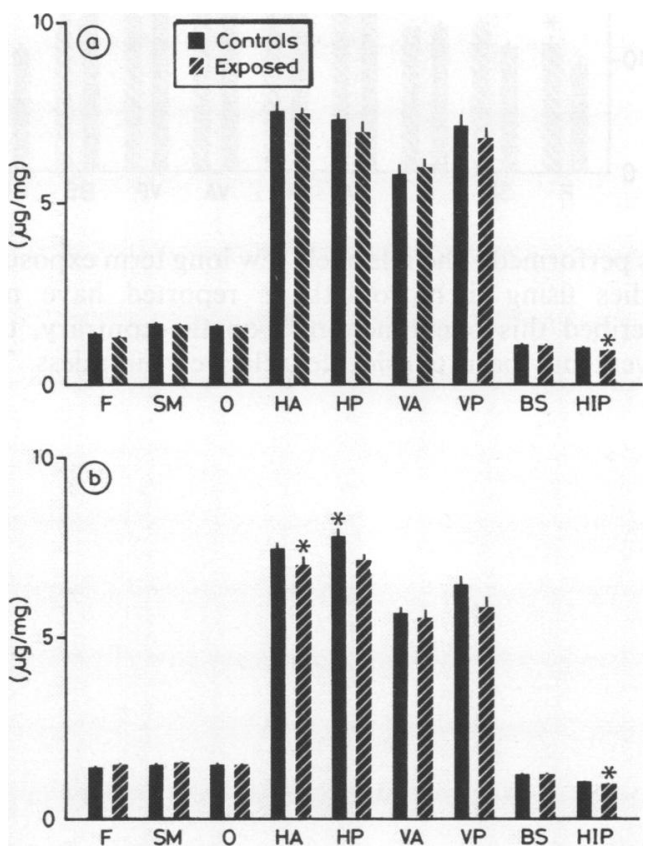

Fig 4 DNA concentrations per wet weight ( $\mu / m g)$ in gerbil brain areas after exposure to dichloromethane at (a) 210 ppm for three months and (b) 350 ppm for two months, followed by a postexposure solvent free period of four months. F: frontal cerebral cortex; SM: sensory motor cerebral cortex; $O$ : occipital cerebral cortex; $H A$ : anterior cerebellar hemispheres; HP: posterior cerebellar

hemispheres; $V A$ : anterior cerebellar vermis; VP: posterior cerebellar vermis; BS: brain stem; HIP: hippocampus. Bars represent mean values of eight animals and SEM. ${ }^{*} p<0.05$. 

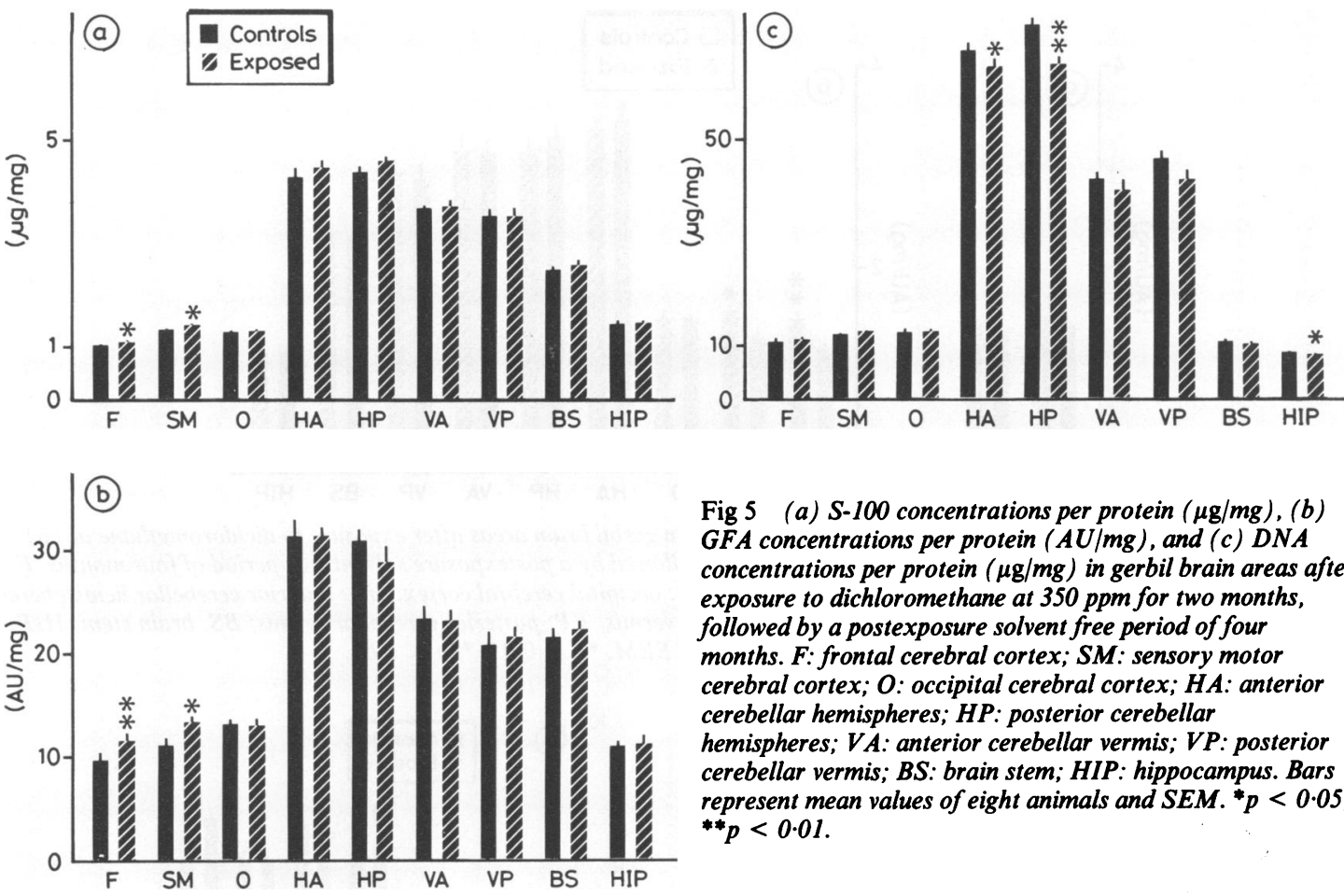

Fig 5 (a) $S$ - 100 concentrations per protein $(\mu \mathrm{g} / \mathrm{mg}),(b)$ GFA concentrations per protein $(A U / m g)$, and (c) DNA concentrations per protein $(\mu \mathrm{g} / \mathrm{mg})$ in gerbil brain areas after exposure to dichloromethane at $350 \mathrm{ppm}$ for two months, followed by a postexposure solvent free period of four months. F: frontal cerebral cortex; SM: sensory motor cerebral cortex; O: occipital cerebral cortex; HA: anterior cerebellar hemispheres; HP: posterior cerebellar

hemispheres; VA: anterior cerebellar vermis; VP: posterior cerebellar vermis; BS: brain stem; HIP: hippocampus. Bars represent mean values of eight animals and SEM. ${ }^{*} p<0.05$; ${ }^{* *} p<0.01$.

was performed. The relatively few long term exposure studies using dichloromethane reported have not described this phenomenon ${ }^{29}$; on the contrary, the solvent has been considered relatively harmless. To

our knowledge, however, none of these studies has used continuous exposure but has been workday related. Moreover, as dichloromethane has a high vapour pressure and is relatively water soluble, but
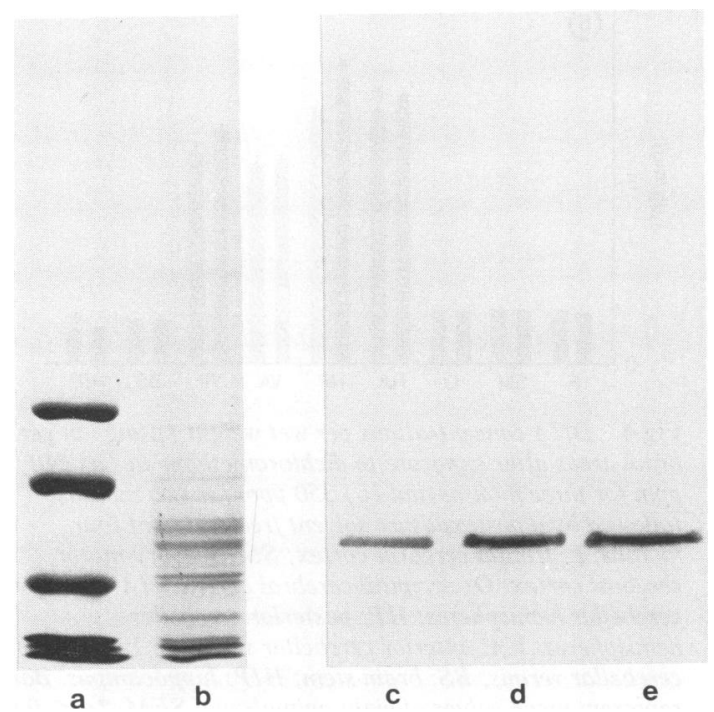

Fig 6 Electrophoretic separation in a SDS polyacrylamid gradient gel (5-10\%). Lane (a): molecular weight standards (from above: phosphorylase b: 94000 , bovine serum albumin: 67000, ovalbumin: 43000 , carbonic anhydrase: 30000 , soyabean trypsin inhibitor: $20100, \alpha$-lactalbumin: 14400). Lane (b): the reference gerbil supernatant containing $27 \mu \mathrm{g}$ protein. Stained with Commassie brilliant blue. Electroblott of samples of the reference gerbil supernatant containing (c): $54 \mu \mathrm{g},(d): 162 \mu \mathrm{g}$, and (e): $270 \mu \mathrm{g}$ protein; subjected to electrophoresis as in (b). Detection was performed using anti-GFA (diluted 1:10000) as first antibody and peroxidase conjugated swine antirabbit IgG as second antibody.

Diaminobenzidine was used for colour reaction. 
less lipid soluble than other chlorinated solvents, ${ }^{30}$ it is rapidly exhaled after exposure. Thus in workday related long term exposure experiments there should be only a slight risk of accumulation of dichloromethane in the lipid rich tissues of the experimental animal. During continuous exposure experiments, however, accumulation of dichloromethane in the animal tissues is probable, especially if a limited metabolising capacity of the solvent is postulated. ${ }^{31}$ These findings necessitate further studies comparing the adverse effects of the solvent on the living organism after continuous and workday related exposure experiments.

In man certain brain areas seem to be more vulnerable to chronic dichloromethane exposure. ${ }^{7}$ In previous studies a varying sensitivity of different brain regions to changes in glial cell $\mathrm{S}-100$ protein has been shown after exposure to trichloroethylene $e^{1321}$ and ethanol. ${ }^{14}$ In order to elucidate this discrete brain regions were investigated in this study.

The $\mathrm{S}-100$ protein is mainly found in protoplasmic and fibrillary astrocytes of the brain. ${ }^{32}$ Hence, the localisation and the high solubility of the S-1009 makes this protein a suitable marker for an astroglial cell increase in response to brain damage. ${ }^{123334}$ The GFA protein is the main component of the astroglial filaments. ${ }^{835}$ Thus GFA is a suitable marker for an astroglial fibre increase in response to brain injury. ${ }^{101136}$

Consequently, the increased concentrations of S100 and GFA observed in the frontal cerebral cortex and the sensory motor cerebral cortex, after the 350 ppm exposure, are compatible with an astroglial hypertrophy or proliferation, or both, and with an astrogliosis in these regions. Hypothetically, the increased concentrations of GFA could also reflect a redistribution between soluble and insoluble GFA, due either to disassembly ${ }^{37}$ or to proteolytic degradation of the glial filaments. ${ }^{38}$ As the concentrations of S-100 and GFA are increased simultaneously, however, this seems unlikely.

Assuming a diploid DNA content in the brain cells, and a metabolic stability of DNA in an adult brain, ${ }^{39-41}$ the DNA concentration represents a measure of the mean density of cells, reflecting the different cellular components of the central nervous system. In this context a concomitant increase of DNA and astroglial protein concentrations could possibly be used as an indication of astroglial proliferation in response to brain injury. In this study, however, the DNA concentrations were not increased in the frontal cerebral cortex and the sensory motor cerebral cortex; on the contrary, decreased DNA concentrations were obvious in the hippocampus after exposure to both 210 and $350 \mathrm{ppm}$ and also in the cerebellar hemispheres after the $350 \mathrm{ppm}$ exposure.
These observations indicate a decreased cell density in these brain regions that may be due to a loss of cells. Cell loss might be ascribed to cell death of, for example, nerve or oligodendroglial cells, or inhibition of the slow non-neuronal cell acquisition phase in the adult brain. ${ }^{42}$ Inhibition of DNA synthesis by dichloromethane has previously been described in a tissue culture system, using hamster epithelial cells and human fibroblasts. ${ }^{43}$ Cellular events occurring during changes of the normal environment of brain cells, especially with regard to neurotoxins, is obviously complex. In areas with increased astroglial protein concentrations, a proliferation of astroglial cells might contribute to "normalised" DNA concentrations, whereas a loss among other cells than astroglia could mask a rise in DNA concentrations. Accordingly, after exposure at $350 \mathrm{ppm}$, no brain area simultaneously displayed increased concentrations of astroglial proteins and decreased concentrations of DNA.

It is not known whether the astroglial reactivity observed is caused by a primary action of dichloromethane on the astroglial cells, or is an indirect reaction in response to, for example, neuronal damage. Astroglial proteins have previously been used to show the occurrence of progressive astroglial reactivity both as a consequence of nerve cell injury in retrograde degeneration of the thalamic nuclei, ${ }^{33}$ and in response to direct tissue damage such as cortical stab wounds. ${ }^{1011}$

The mechanism behind the neurotoxicity of dichloromethane is unclear. Since dichloromethane is lipid soluble ${ }^{30}$ interference with the biological membranes of the brain could be one cause of the biochemical alterations observed. Furthermore, the relation between the metabolism of dichloromethane and the neurotoxicity of the compound is not fully understood. Dichloromethane is metabolised in the rat liver by two major pathways of biotransformation. The first pathway described follows oxidation by the microsomal cytochrome P-450 mono-oxygenases, ultimately yielding carbon monoxide ${ }^{44}$; the second follows conjugation to glutathione leading to formation of formaldehyde. ${ }^{45}$ In a complementary experiment carboxyhaemoglobin concentrations were determined in gerbils exposed to 210 or $350 \mathrm{ppm}$ dichloromethane by continuous inhalation. Assuming that three weeks exposure renders steady state carboxyhaemoglobin concentrations, the similar carboxyhaemoglobin concentrations observed at these two exposure levels indicate a limited metabolising capacity of the microsomal cytochrome P-450 mono-oxygenases, in agreement with earlier studies. ${ }^{2931}$ As the biochemical alterations induced in the gerbil brain were only minor after exposure to 210 ppm, but pronounced after exposure to $350 \mathrm{ppm}$, 
these results do not favour the hypothesis that carboxyhaemoglobin induced cerebral hypoxia is the major cause of dichloromethane induced brain dysfunction as previously suggested. ${ }^{7}$

As both the major pathways of dichloromethane metabolism are present to some extent in the rat brain, ${ }^{4546}$ local metabolite formation could be of importance to explain the neurotoxicity of the compound. Dichloromethane derived ${ }^{14} \mathrm{C}$ activity has been described in the rat brain 48 hours after a short time exposure, probably reflecting binding of metabolites to macromolecules or to the incorporation of dichloromethane derived one carbon fragments into normal metabolic pathways. ${ }^{3147}$ One metabolite, formaldehyde, is a well recognised toxin, which is known to bind covalently to tissue macromolecules. ${ }^{48}$

It is suggested that astroglial reactions are a common feature after long term exposure to some solvents, ${ }^{131449}$ as well as to dichloromethane, and that the changes observed are irreversible as they occur despite a postexposure solvent free period. These alterations serve as an indicator of solvent induced brain damage and they are in accordance with the signs of diffuse toxic brain damage described by von Hanke et $a l^{5}$ and von Weiss ${ }^{6}$ after chronic occupational exposure to dichloromethane.

This work has been supported by the Swedish Work and Environmental Fund (ASF 82-0649, ASF 83-0810, and ASF 84-0217). Eva Åwall's and MajBritt Johansson's skilful technical help is gratefully acknowledged as is Leif Trulsson, of Göteborgs Datacentral, for statistical advice.

\section{References}

${ }^{1}$ Stewart RD, Fisher TN, Hosko MJ, Peterson JE, Baretta ED, Dood HC. Experimental human exposure to methylene chloride. Arch Environ Health 1972;25:342-8.

${ }^{2}$ Stewart RD, Hake CL. Paint-remover hazard. JAMA 1976; 235:398-401.

${ }^{3}$ Winneke G, Fodor GG. Dichloromethane produces narcotic effect. International Journal of Occupational Health and Safety 1976;45:34-49.

${ }^{4}$ Winek CL, Collom WD, Esposito F. Accidental methylene chloride fatality. Forensic Sci Int 1981;18:165-8.

${ }^{5}$ von Hanke $C$, Ruppe $K$, Otto J. Untersuchungsergebnisse zur toxischen Wirkung von Dichlormethan bei Fussbodenlegern. $Z$ Gesamte Hyg 1974;20:81-4.

${ }^{6}$ von Weiss G. Toxische Enzephalose beim beruflichen Umgang mit Methylenchlorid. Zentralblatt für Arbeitsmedizin und Arbeitsschutz 1967;17:282-5.

${ }^{7}$ Barrowcliff DF, Knell AJ. Cerebral damage due to endogenous chronic carbon monoxide poisoning caused by exposure to methylene chloride. J Soc Occup Med 1979;29:12-4.

${ }^{8}$ Eng LF, Vanderhaeghen JJ, Bignami A, Gerstl B. An acidic protein isolated from fibrous astrocytes. Brain Res 1971;28:351-4.

${ }^{9}$ Moore BW. A soluble protein characteristic of the nervous system. Biochem Biophys Res Commun 1965;19:739-44.
${ }^{10}$ Bignami A, Dahl D. The astroglial response to stabbing. Immunofluorescence studies with antibodies to astrocytespecific protein (GFA) in mammalian and submammalian vertebrates. Neuropathol Appl Neurobiol 1976;2:99-110.

${ }^{11}$ Latov N, Nilaver G, Zimmerman EA, et al. Fibrillary astrocytes proliferate in response to brain injury. Dev Biol 1979;72:381-4.

${ }^{12}$ Molin S-O, Nyström B, Haglid KG, Hamberger A. Glial contribution to amino acid content and metabolism of the deafferented dentate gyrus. $J$ Neurosci Res 1984;11:1-11.

${ }^{13}$ Haglid KG, Briving C, Hansson H-A, et al. Trichloroethylene: long-lasting changes in the brain after rehabilitation. Neurotoxicology 1981;2:659-73.

${ }^{14}$ Rosengren LE, Wronski A, Briving C, Haglid KG. Long lasting changes in gerbil brain after chronic ethanol exposure: a quantitative study of the glial cell marker S-100 and DNA. Alcoholism (NY) 1985;9:109-13.

${ }^{15}$ Putz VR, Johnson BL, Setzer JV. A comparative study of the effects of carbon monoxide and methylene chloride on human performance. J Environ Pathol Toxicol 1979;2:97-112.

${ }^{16}$ Lowry OH, Rosebrough NJ, Farr AL, Randall RJ. Protein measurement with the folin phenol reagent. $J$ Biol Chem 1951;193:265-75.

${ }^{17}$ Stavrou D, Lübbe I, Haglid KG. Immunelektrophoretische Quantifizierung des hirnspezifischen S-100-Proteins. Acta Neuropathol (Berl) 1974;29:275-80.

${ }^{18}$ Kissane JM, Robins E. The fluorometric measurement of deoxyribonucleic acid in animal tissues with special reference to the central nervous system. J Biol Chem 1958;233:184-8.

${ }^{19}$ Engvall E, Perlmann P. Enzyme-linked immunosorbent assay (ELISA). Quantitative assay of immunoglobulin G. Immunochemistry 1971;8:871-4.

${ }^{20}$ Gheuens J, Noppe M, Karcher D, Lowenthal A. Immunochemical determination and immunocytological localization of brainspecific protein alpha-albumin (GFA) in isolated astrocytes. Neurochem Res 1980;5:757-68.

${ }^{21}$ Haglid KG, Kjellstrand P, Rosengren LE, Wronski A, Briving C. Effects of trichloroethylene inhalation on proteins of the gerbil brain. Arch Toxicol 1980;43:187-99.

${ }^{22}$ Dahl D, Bignami A. Glial fibrillary acidic protein from normal and gliosed human brain. Demonstration of multiple related polypeptides. Biochimica et Biophysica Acta 1975;386:41-51.

${ }^{23}$ Laemmli UK. Cleavage of structural proteins during the assembly of the head of bacteriophage T4. Nature 1970;227:680-5.

${ }^{24}$ Towbin H, Staehelin T, Gordon J. Electrophoretic transfer of proteins from polyacrylamide gels to nitrocellulose sheets: procedure and some applications. Proc Natl Acad Sci USA 1979;76:4350-4.

${ }^{25}$ Collison HA, Rodkey FL, O'Neal JD. Determination of carbon monoxide in blood by gas chromatography. Clin Chem 1968;14:162-71.

${ }^{26}$ Lundh B, Johansson M-B, Mercke C, Cavallin-Ståhl E. Enhancement of heme catabolism by caloric restriction in man. Scand $J$ Clin Lab Invest 1972;30:421-7.

${ }^{27}$ Bradley JV. Distribution-free statistical tests. Englewood Cliffs: Prentice-Hall, Inc, 1968:68-86.

${ }^{28}$ Cotman CW, Nadler JV. Reactive synaptogenesis in the hippocampus. In: Cotman CW, ed. Neuronal plasticity. New York: Raven Press, 1978:227-71.

${ }^{29}$ Burek JD, Nitschke KD, Bell TJ, et al. Methylene chloride: a twoyear inhalation toxicity and oncogenicity study in rats and hamsters. Fundamental and Applied Toxicology 1984;4:30-47.

${ }^{30}$ Sato A, Nakajima T. A structure-activity relationship of some chlorinated hydrocarbons. Arch Environ Health 1979;34:69-75.

${ }^{31}$ McKenna MJ, Zempel JA, Braun WH. The pharmacokinetics of inhaled methylene chloride in rats. Toxicol Appl Pharmacol 1982;65:1-10.

${ }^{32}$ Haan EA, Boss BD, Cowan WM. Production and characterization of monoclonal antibodies against the "brain-specific" proteins 14-3-2 and S-100. Proc Natl Acad Sci USA 1982;79:7585-9.

${ }^{33}$ Cicero TJ, Cowan WM, Moore BW, Suntzeff V. The cellular local- 
ization of the two brain specific proteins. S-100 and 14-3-2. Brain Res 1970;18:25-34.

${ }^{34}$ Perez VJ, Olney JW, Cicero TJ, Moore BW, Bahn BA. Wallerian degeneration in rabbit optic nerve: cellular localization in the central nervous system of the S-100 and 14-3-2 proteins. $J$ Neurochem 1970;17:511-9.

${ }^{35}$ Bignami A, Eng LF, Dahl D, Uyeda CT. Localization of the glial fibrillary acidic protein in astrocytes by immunofluorescence. Brain Res 1972;43:429-35.

${ }^{36}$ Dahl D, Crosby CJ, Bignami A. Filament proteins in rat optic nerves undergoing Wallerian degeneration. Exp Neurol 1981;71:421-30.

${ }^{37}$ Rueger DC, Huston JS, Dahl D, Bignami A. Formation of $100 \AA$ filaments from purified glial fibrillary acidic protein in vitro. $J$ Mol Biol 1979;135:53-68.

${ }^{38}$ DeArmond SJ, Fajardo M, Naughton SA, Eng LF. Degradation of glial fibrillary acidic protein by a calcium dependent proteinase: an electroblot study. Brain Res 1983;262:275-82.

${ }^{39}$ Hobi R, Studer M, Ruch F, Kuenzle CC. The DNA content of cerebral cortex neurons. Determinations by cytophotometry and high performance liquid chromatography. Brain Res 1984;305:209-19.

${ }^{40}$ Mann DMA, Yates PO. A quantitative study of the glia of the Purkinje cell layer of the cerebellum in mammals. Neuropathol Appl Neurobiol 1979;5:71-6.

${ }^{41}$ Mares V, Schultze B, Maurer W. Stability of DNA in Purkinje cell nuclei of the mouse. An autoradiographic study. J Cell Biol 1974;63:665-74.
${ }^{42}$ Korr H. Proliferation of different cell types in the brain. Adv Anat Embryol Cell Biol 1980;61:1-72.

43 Jongen WMF, Lohman PHM, Kottenhagen MJ, Alink GM, Berends F, Koeman JH. Mutagenicity testing of dichloromethane in short-term mammalian test systems. Mutat Res 1981;81:203-13.

${ }^{44}$ Kubic VL, Anders MW. Metabolism of dihalomethanes to carbon monoxide. II. In vitro studies. Drug Metab Dispos 1975;3:104-12.

${ }^{45}$ Ahmed AE, Anders MW. Metabolism of dihalomethanes to formaldehyde and inorganic halide. In vitro studies. Drug Metab Dispos 1976;4:357-61.

${ }^{46}$ Marietta MP, Vesell ES, Hartman RD, Weisz J, Dvorchik BH. Characterization of cytochrome P-450-dependent aminopyrine $\mathrm{N}$-demethylase in rat brain: comparison with hepatic aminopyrine N-demethylation. J Pharmacol Exp Ther 1979;208:271-9.

${ }^{47}$ McKenna MJ, Zempel JA. The dose-dependent metabolism of $\left({ }^{14}\right) \mathrm{C}$-methylene chloride following oral administration to rats. Food and Cosmetic Toxicology 1981;19:73-8.

${ }^{48}$ Casanova-Schmitz M, Starr TB, H d'A Heck. Differentiation between metabolic incorporation and covalent binding in the labeling of macromolecules in the rat nasal mucosa and bone marrow by inhaled $\left({ }^{14} \mathrm{C}\right)$ - and $\left({ }^{3} \mathrm{H}\right)$ formaldehyde. Toxicol $\mathrm{Appl}$ Pharmacol 1984;76:26-44.

${ }^{49}$ Rosengren LE, Aurell A, Kjellstrand P, Haglid KG. Astrogliosis in the cerebral cortex of gerbils after long-term exposure to 1,1,1-trichloroethane. Scand J Work Environ Health 1985;11:447-55.

\section{Correspondence and editorials}

The British Journal of Industrial Medicine welcomes correspondence relating to any of the material appearing in the journal. Results from preliminary or small scale studies may also be published in the correspondence column if this seems appropriate. Letters should be not more than 500 words in length and contain a minimum of references. Tables and figures should be kept to an absolute minimum. Letters are accepted on the understanding that they may be subject to editorial revision and shortening.

The journal now also publishes editorials which are normally specially commissioned. The Editor welcomes suggestions regarding suitable topics; those wishing to submit an editorial, however, should do so only after discussion with the Editor. 